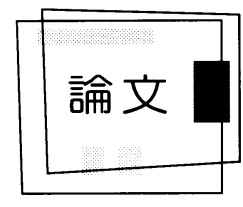

\title{
クロスヘッド軸受の焼付き発生防止のための 異常振動検知に関する研究*
}

\author{
北原 辰 巳** 山本 壮 晃*** \\ 大坪 勝 $* * *$ 中 原 大 輔 $* * * *$
}

Monitoring of Abnormal Vibration to Prevent Seizure of Crosshead Bearings

By Tatsumi Kitahara, Hiroaki Yamamoto, Masaru Otsubo, and Daisuke Nakahara

The crosshead bearing in large two-stroke diesel engines operates under severe lubrication conditions because hydrodynamic action is limited by low-amplitude, low- velocity oscillation under high specific load. The recent trend toward more compact engines with increased output raises the bearing specific load, thereby significantly increasing the lubrication severity. Therefore it is very important to find a means of preventing seizure of the crosshead bearing. In this study we evaluated a technique for monitoring abnormal vibration using a dynamically loaded bearing seizure test rig capable of simulating load patterns and relative oscillations of the crosshead bearing in actual engines. Vibration spikes occur around the crank angles of \pm 90 degrees where the oscillating speed is zero during each cycle. When the lubrication severity increases, an abnormal vibration spike caused by severe metal-to-metal contact is frequently generated at a crank angle of approximately 90 degrees, where the oil film thickness reaches a minimum. If running-in is properly carried out immediately after detection of the abnormal vibration, the bearing surface is conformed, thereby eliminating the severe metal-to-metal contact. This monitoring technique for abnormal vibration can be an effective means of preventing seizure of the crosshead bearing.

\section{1. 緒 言}

大形 2 サイクルディーゼル機関のクロスヘッド軸 受 (図1) は, 高い荷重が常に下向きに作用するこ とと小さい摇動運動しか行わないという特徴が重 なるため，軸受面に形成される油膜が極めて薄く 焼損や破損を起こしやすい滑り軸受である. 近年 は大形機関の高出力化やコンパクト化が進みクロ スヘッド軸受の潤滑状態は一段と苛酷化する傾向 にあり，損傷発生の防止策を検討することが重要 な課題になっている(1) 5).

\footnotetext{
*原稿受付 平成 15 年 11 月 6 日

**正 会員 九州大学大学院 (福岡市東区箱崎 6-10-1)

$* * *$ 非会員 九州大学大学院 (福岡市東区箱崎6-10-1)

$* * * *$ 非会員 大同メタル工業株式会社

（愛知県犬山市大字前原字天道新田）
}

一般に摺動面で形成された油膜が破断し固体接 触が発生した場合でも初期段階で閏滑状態の異常 を検知できれば，その直後に適正ななじみ運転を 実施することにより油膜が修復され損傷発生を防 止できるものと考えられる。しかし異常の検知が 遅れると潤滑状態は一段と苛酷になり損傷発生に 至る場合が多い。潤滑状態の異常を検知する手段 として，摺動面近傍の振動状態をモニタリングす ることが有効であると考えられ，転がり軸受や蒾 車などで適用された例は多く報告されている ${ }^{6)}$. 大 形ディーゼル機関でもピストンリング摺動面や燃 焼などの異常を検知する手段として適用された例 がある7) 9) 。一方, 滑り軸受に関しては高速条件 下で作動する軸受を対象にオイルホワールやオイ ルホイップなどの異常現象を防止する目的から振 動状態を解析した研究は多いが, クロスヘッド軸 
受のような低速の摇動軸受で振動状態をモニタリ ングし異常診断を実施した研究はほとんど報告さ れておらず，不明な点が多い.

そこで本研究では実際機関のクロスヘッド軸受と 同様な変動荷重, 摇動すべりの条件で焼付き試験が 実施できる軸受試験機に加速度センサーを装着して 運転中の振動状態をモニタリングすることにより， 苛酷な固体接触が発生した初期段階で異常振動を検 知し焼付き発生を防止する方策について検討した。

\section{2. 実験方法}

図2に軸受試験機の概略を示す，直径 $100 \mathrm{~mm} の$ 試験軸(1)は，その両側をコロ軸受(3)で支持されて クランク機構(4)により摇動運動を行う。試験軸受 (2)には油圧ラム5)により垂直下向きの変動荷重が 与えられる。罒3に示すように, 軸受面圧 $\mathrm{P}_{\mathrm{w}}$ はク ランク角度 $\theta_{\mathrm{c}}=0^{\circ}$ (上死点：TDC) で最大となる。 軸の摇動角速度 $\omega$ は $\theta_{\mathrm{c}}=-90^{\circ}$ および+ $90^{\circ}$ で零 となり, $\theta_{\mathrm{c}}=0^{\circ}$ おび $180^{\circ}$ (下死点：BDC)で絶 対值が各々最大となる。本試験機では軸受と荷重 の方向が固定され, 軸のみが摇動角 $2 \psi$ で摇動回 転する構造であるが，実際機関のクロスヘッド軸

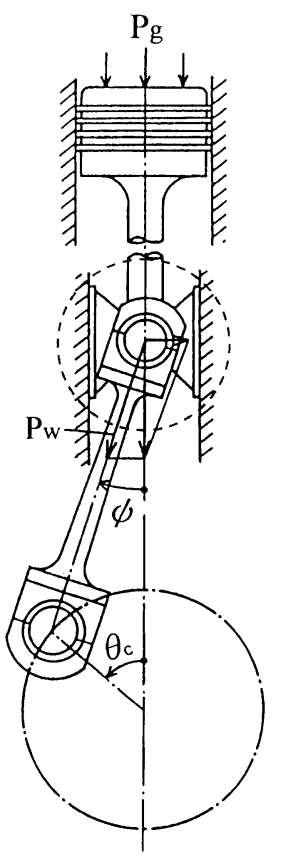

図1 Crosshead bearing
受と同様な変動荷重, 摇動滑りの条件で焼付き試 験が実施できるようになっている。供試潤滑油は SAE10Wの無添加エンジン油であり, 一定温度 $60{ }^{\circ} \mathrm{C}$ で軸受メタルに供給した。罒4に軸受メタル の主要寸法を示す。軸受合金はホワイトメタルを 用い, 軸受すき間比 $\mathrm{c} / \mathrm{r}$ (軸と軸受の半径すき間： c, 軸半径：r) は 0.0001 または 0.0005 に設定した。

本研究では給油停止による焼付き試験と荷重増 加による焼付き試験を実施して, 試験開始から焼

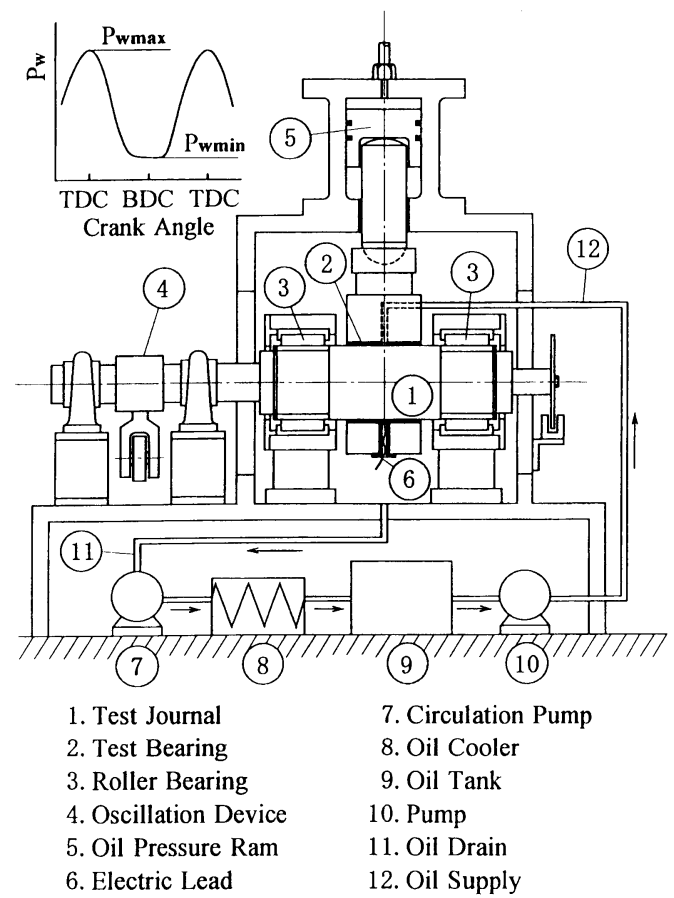

図2 Schematic diagram of test apparatus

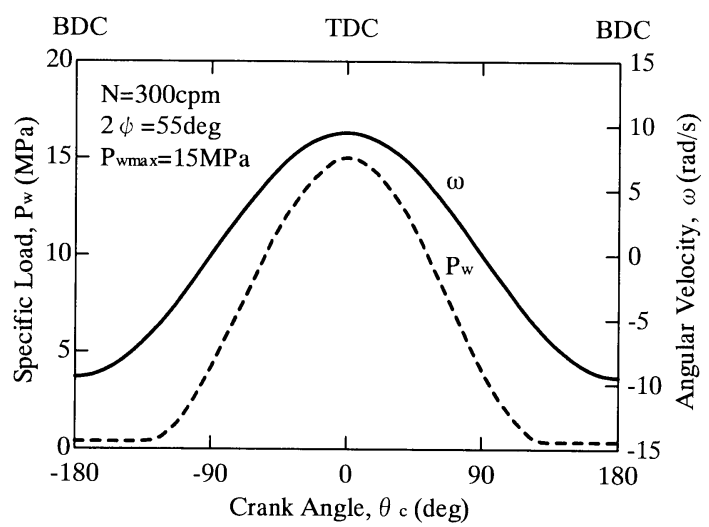

图3 Typical changes in specific load and angular velocity during one cycle 
付き発生に至るまでの軸受表面温度, 振動状態, 並 びに油膜形成状態の変化を調べた. 四5に示すよう に, 軸受表面温度は軸受中央部の表面から $0.5 \mathrm{~mm}$ の深さに埋込んだ熱電対で測定した。 また軸受振動 状態は軸受ハウジングに加速度センサーを装着し， 軸の摇動方向の振動加速度を測定することにより 解析した。ささに油膜形成状態は図6に示すような 電気回路を用い，油膜の電気抵抗を測定することに より検討した ${ }^{10)}$. すなわち軸受メタルと軸受ハウジ ングを電気的に絶縁して軸受メタルに $273 \mathrm{mV}$ の電 圧を加えた場合, 軸と軸受メタル間の出力電圧 $\mathrm{E}$ と 油膜の電気抵抗Rには図7に示すような関係が成立 する. 例えば軸受面に厚い油膜が形成され軸と軸受
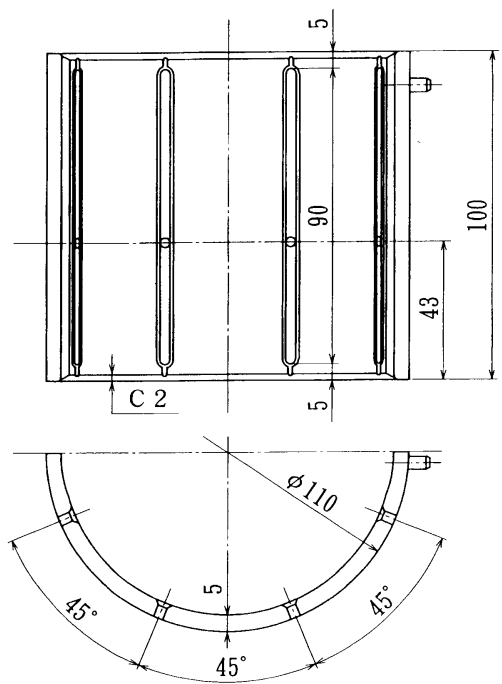

図4 Major dimensions of test bearing

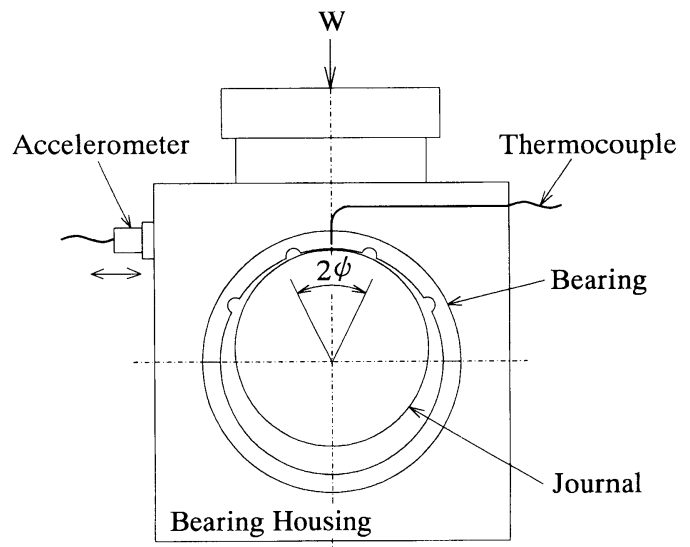

図5 Location of vibration accelerometer and thermocouple
が完全に分離した状態では電気抵抗が極めて高く

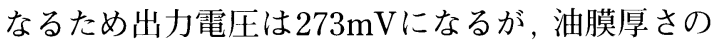
減少により固体接触の度合いが増すと電気抵抗が 低くなり出力電圧は $0 \mathrm{mV}$ に低下する。

\section{3. 実験結果と考察}

\section{1 給油停止による焼付き試験}

3.1.1 振動波形の特徵 図8は軸受すき間比 $\mathrm{c} / \mathrm{r}=0.0001$, 摇動速度 $\mathrm{N}=300 \mathrm{cpm}$, 摇動角 $2 \psi=$ $55 \mathrm{deg}$, 並びに最高軸受面圧 $\mathrm{P}_{\mathrm{w} \text { max }}=18 \mathrm{MPa}$ の一定条 件で十分ななじみ運転を実施した後, 潤滑油の供給 を停止して焼付きが発生するまでの軸受振動加速度

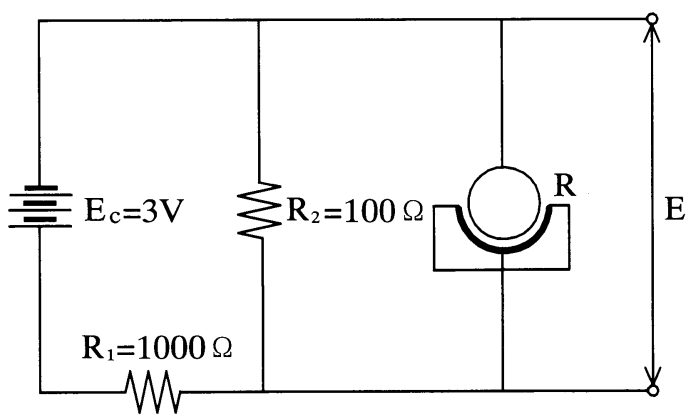
R: Resistance of Oil Film E: Output Voltage

$$
E=\frac{R \cdot R_{2} \cdot E_{c}}{R_{1} \cdot R_{2}+R\left(R_{1}+R_{2}\right)}
$$

図6 Electrical circuit to measure electrical resistance of oil film

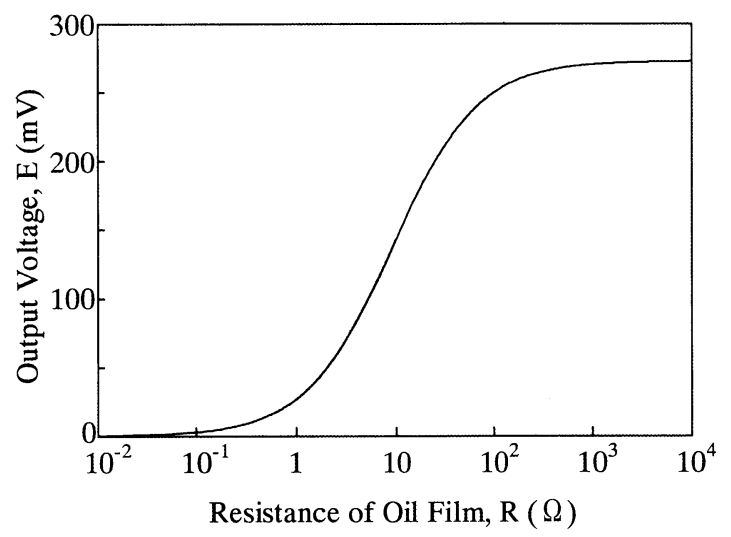

図7 Relationship between output voltage and electrical resistance of oil film 


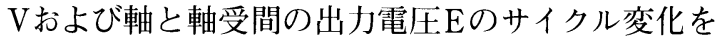
調べた結果である. 図中のF值は油膜形成率を, X 值は3.1.2節で検討する異常振動発生率を各々示す.

図8 (a) は給油停止前の安定した潤滑状態で得ら れた結果である. 振動波形の特徴として試験装置の 固有振動によるものと考えられる周波数 $350 \mathrm{~Hz}$ の振 動の他に, 1 サイクルに2回すなわち摇動方向が反 転する $\theta_{\mathrm{c}}=-90^{\circ}$ および+ $90^{\circ}$ 近傍で高い振幅の振 動スパイクが発生することが認められる．振動スパ イクが発生した原因として, 摇動方向の逆転に伴い 摩擦力が急増し ${ }^{11)}$ スティックスリップが発生したこ とが推察できる。一方, 油膜形成状態の特徴として 荷重の低い $\theta_{\mathrm{c}}=180^{\circ}$ 近傍では比較的厚い油膜が形 成されるため出力電压は $273 \mathrm{mV}$ となるが, 高い荷 重が作用する $\theta_{\mathrm{c}}=0^{\circ}$ 近傍から $120^{\circ}$ までの期間では 油膜が破断し出力電圧は $0 \mathrm{mV}$ まで低下することが 認められる。このように出力電圧は1サイクル中に 大きく変化するため, 図9に示す (2) 式から油膜形 成率 $\mathrm{F}$ の值を求め, 油膜形成状態を評価した.
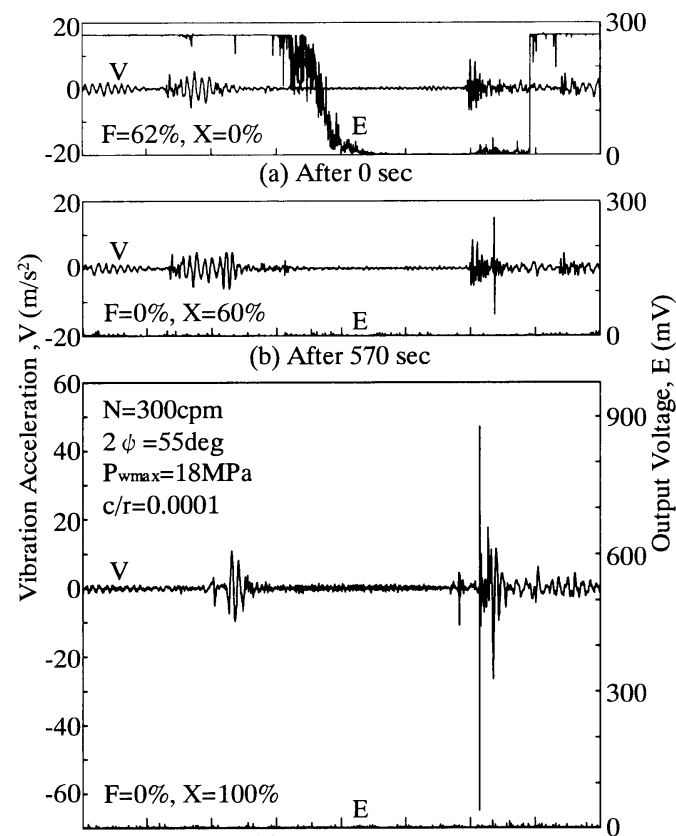

(c) After $790 \mathrm{sec}$

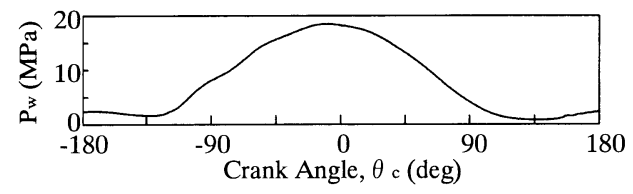

目8 Changes in vibration acceleration and output voltage during one cycle 図8（b）は給油を停止して570秒後に得られた結 果であるが, 潤滑状態が苛酷になると出力電圧は 1 サイクルを通して常に $0 \mathrm{mV}$ となり, 油膜形成状態 が悪化することがわかる。また給油停止前の振動 波形と比較して $\theta_{\mathrm{c}}=+90^{\circ}$ 近傍の振動スパイクに 顕著な増加が認められる。さらに四8 8 (c) は給油を 停止して790秒後の焼付き発生直前に得られた結果 であるが，潤滑状態が一段と苛酷になると $\theta$ c $=+90^{\circ}$ 近傍の振動スパイクは大幅に増大する特徴 が認められる.

図10は1サイクルに抢けるクロスヘッド軸受の 最小油膜厚さ $\mathrm{h}_{\min }$ の変化を理論計算により求めた 結果である ${ }^{12)}$ 。クロスヘッド軸受の油膜厚さは荷 重が最大となる $\theta_{\mathrm{c}}=0^{\circ}$ 近傍で最小にならず，摇動 方向が反転する $\theta_{\mathrm{c}}=+90^{\circ}$ を過ぎて最小になるこ

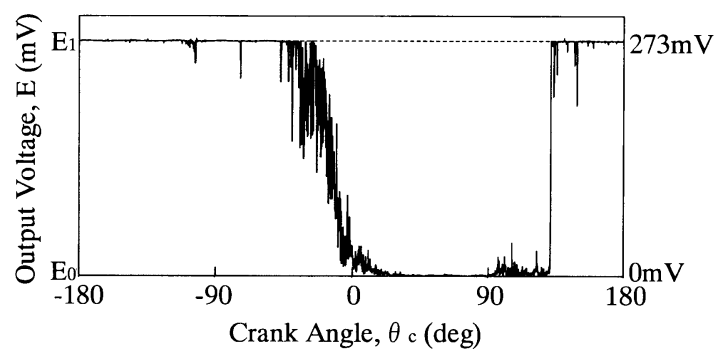

$$
\mathrm{F}=\int_{-180}^{180}\left(\frac{\mathrm{E}-\mathrm{E}_{0}}{\mathrm{E}_{1}-\mathrm{E}_{0}}\right) d \theta_{\mathrm{c}}
$$

\section{図9 Calculation of oil film formation ratio}

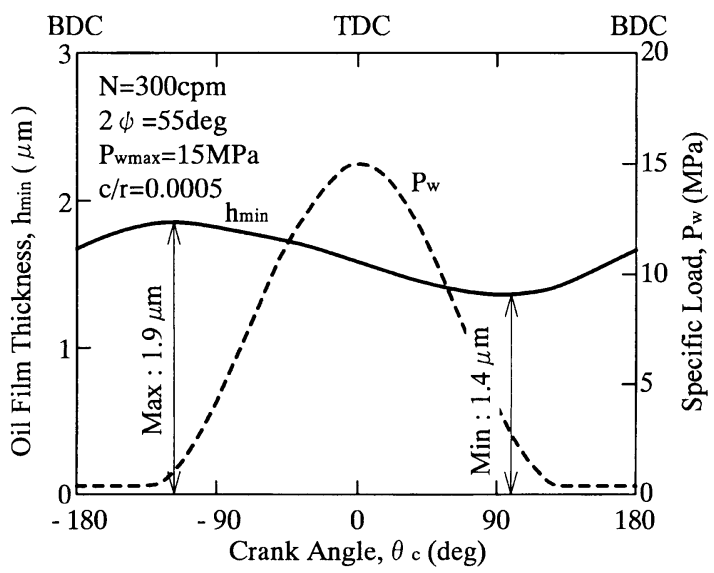

図10 Calculated oil film thickness during one cycle 


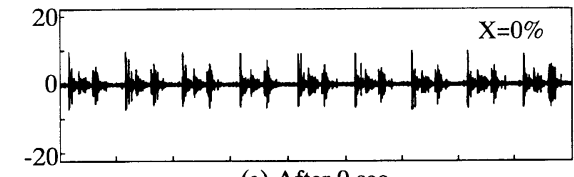

(a) After $0 \mathrm{sec}$

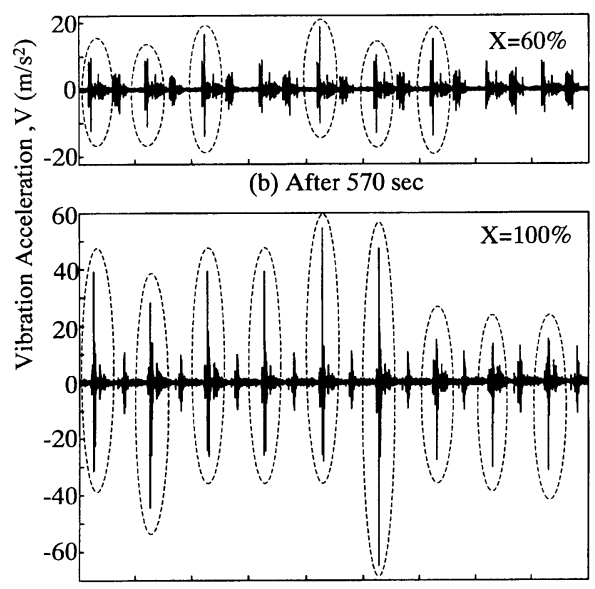

(c) After $790 \mathrm{sec}$

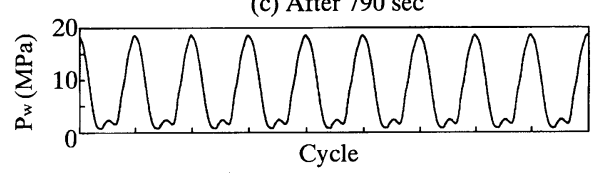

図11 Change in vibration acceleration after stopping oil supply

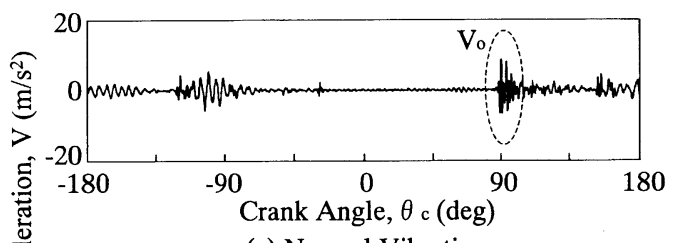

(a) Normal Vibration

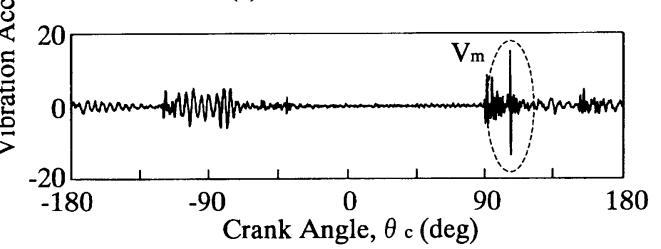

(b) Abnormal Vibration

- $V_{0}$ : Vibration spike under normal lubrication condition

$\cdot V_{\mathrm{m}}$ : Increased vibration spike by raised lubrication severity

- $\mathrm{V}_{\mathrm{cr}}$ : Threshold level of vibration spike $\left(\mathrm{V}_{\mathrm{cr}}=1.2 \mathrm{~V}_{\mathrm{o}}\right)$

-If $V_{m}>V_{\text {cr }}$ : Abnormal vibration

図12 Definition of abnormal vibration
とがわかる。このため給油停止により潤滑状態が 苛酷になると，1サイクル中で油膜厚さが最小とな る $\theta_{\mathrm{c}}=+90^{\circ}$ 近傍における振動スパイクの増大が 顕著に現れたものと推察できる。

困11は給油を停止して焼付きが発生するまでの 振動加速度Vの変化を 10 サイクル通して記録した 結果である。給油停止前の安定した潤滑状態では, 10サイクル全ての振動波形がほぼ同様な変化を繰 返している。しかし給油を停止して570秒後の場 合，各サイクルで振動波形が異なっており $\theta_{\mathrm{c}}=+$ $90^{\circ}$ 近傍の振動スパイクが顕著に増加しているサイ クルと, ほとんど変化していないサイクルが混在 することがわかる。これは潤滑状態が苛酷になっ た初期段階で油膜の破断と修復が繰り返された結 果によるものと推察できる。そして潤滑状態が一 段と苛酷になり焼付きが発生する直前の790秒後の 場合， $\theta_{\mathrm{c}}=+90^{\circ}$ 近傍の振動スパイクが 10 サイク ル全てにおいて大幅に増大する特徴が認められる。
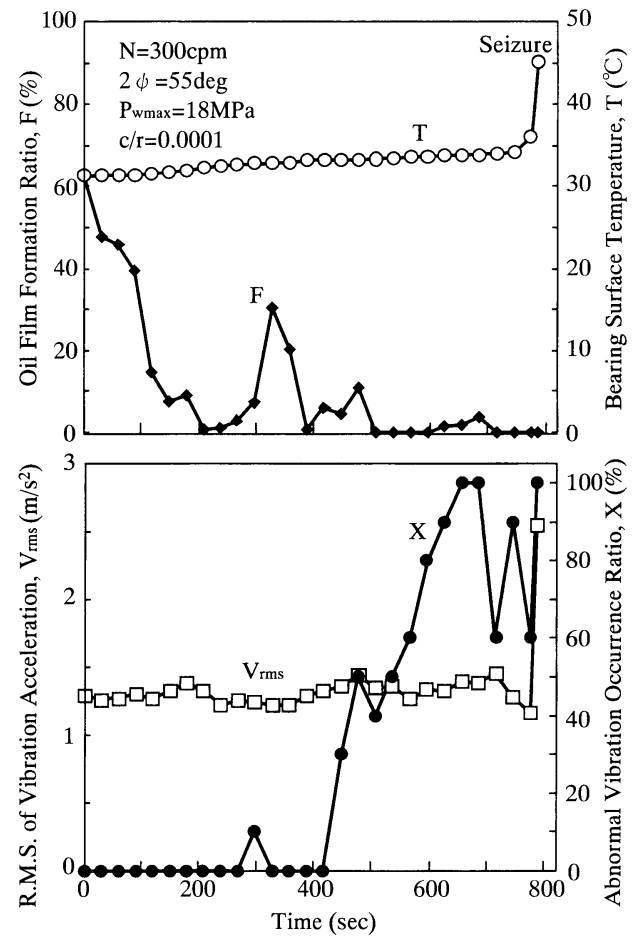

図13 Changes in values of $F, T, V_{r m s}$ and $X$ after stopping oil supply 
3.1 .2 異常診断 前述のような振動波形の特 徵から, $\theta_{\mathrm{c}}=+90^{\circ}$ 近傍に抢ける振動スパイクの 増大とその発生頻度に着目した異常診断法につい て検討する。すなわち図12に示すように給油停止 前の安定した潤滑状態で得られた振動波形におけ る $\theta_{\mathrm{c}}=+90^{\circ}$ 近傍の振動スパイクの絶対值を $\mathrm{V}_{\mathrm{o}}$ と する。潤滑状態が苛酷になると $\theta_{\mathrm{c}}=+90^{\circ}$ 近傍の 振動スパイク $\mathrm{V}_{\mathrm{m}}$ が増大するが，ここで振動スパイ クのしきい值 $\mathrm{V}_{\mathrm{cr}}\left(=1.2 \mathrm{~V}_{\mathrm{o}}\right)$ を定め, 10 サイクル中 でしきい值を超えた異常な振動スパイクの発生数 （異常振動発生率X）を計測する方法で異常診断を 実施した。しきい值の設定に際し，設定值が低す ぎると振動スパイクの僅かな変動により異常振動 発生率が大幅に変化し, 逆に設定值が高いと異常 振動の検知が遅れるという欠点があるため, 本研 究ではしきい值 $\mathrm{V}_{\mathrm{cr}}$ を $1.2 \mathrm{~V}_{\mathrm{o}}$ に設定した。しきい值の 設定に関する理論的考察を含めた詳細な検討は今 後の研究課題である.

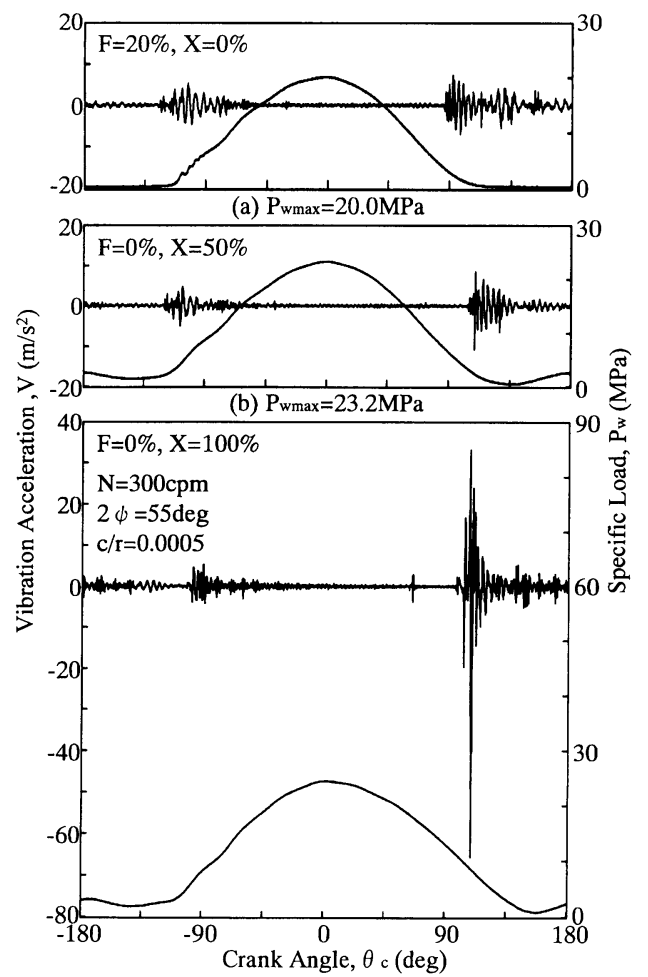

(c) $\mathrm{P}_{\mathrm{wmax}}=24.2 \mathrm{MPa}$

図14 Change in vibration acceleration by raising maximum specific load
図13 は給油を停止して焼付きが発生するまでの 油膜形成率 $\mathrm{F}$, 軸受表面温度 $\mathrm{T}$, 振動加速度の実効 值 $\mathrm{V}_{\mathrm{rms}}$, 並びに異常振動発生率Xの経時変化を調べ た結果である。軸受表面温度 $\mathrm{T}$ 打よび振動加速度 (実効值) $\mathrm{V}_{\mathrm{rms}}$ に関しては給油を停止して770秒後に 急増し，その直後に焼付きが発生した。すなわち 表面温度および振動加速度 (実効值)の急増が検出 された段階では，既に潤滑状態が極めて苛酷な状 態にあるため焼付き発生を防止することは困難で あることがわかる。一方，油膜形成率 $\mathrm{F}$ は軸受面 に軽度な固体接触が発生した場合でも大幅に減少 しており，給油停止後かなり早い段階で $0 \%$ まで低 下している，従って油膜形成率の変化から苛酷な 固体接触の度合いを評価して焼付き発生に至るか どうかの予知診断を行うことは困難であると考え られる。これに対して異常振動発生率Xが $50 \%$ を 越え，高い振幅の振動スパイクが頻繁に発生する ことを異常診断の基準に考えると, 給油を停止し て470秒後に潤滑状態の異常を検知でき，焼付き発 生の予防診断として有効であることがわかる.

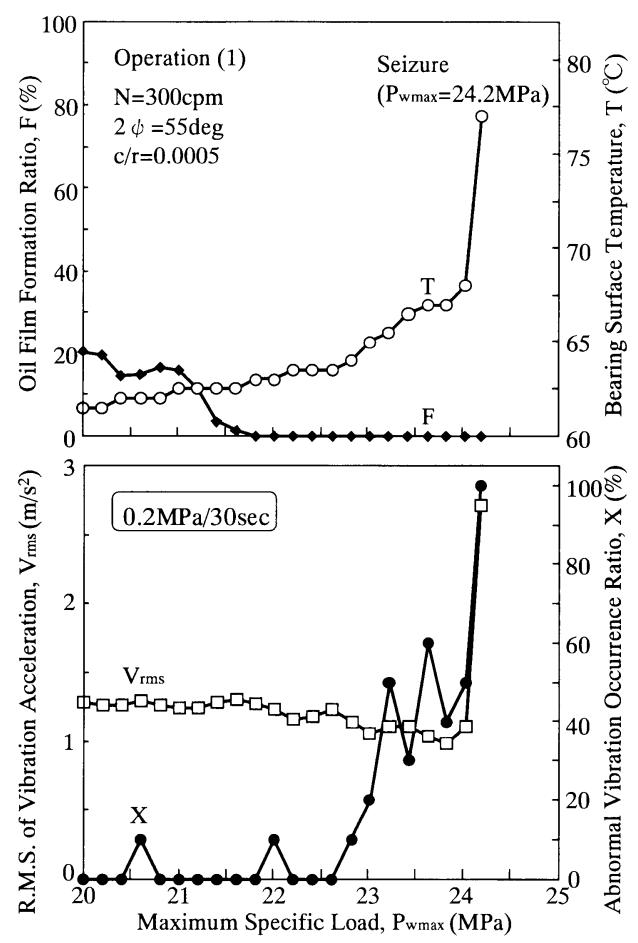

図15 Changes in values of $F, T, V_{\text {rms }}$ and $X$ by raising maximum specific load 


\section{2 荷重増加による焼付試験}

\subsection{1 振動波形の特徵と異常診断困14は軸} の摇動速度 $\mathrm{N}=300 \mathrm{cpm}$, 摇動角 $2 \psi=55 \mathrm{deg}$, 並 びに最高軸受面圧 $P_{\text {wmax }}=20 \mathrm{MPa}$ の一定条件で十分 ななじみ運転を実施した後, $\mathrm{P}_{\mathrm{wmax}}$ 值のみを段階的 $(0.2 \mathrm{MPa} / 30$ 秒の増加率) に増大させて焼付きが発 生するまでの振動波形の変化を調べた結果である. 本節で適用した軸受すき間比 $\mathrm{c} / \mathrm{r}$ の值は 0.0005 であ り, 3.1 節の場合 $(\mathrm{c} / \mathrm{r}=0.0001)$ と比較して大幅に 増大しているが，振動波形の特徵は同様であるこ とがわかる。すなわち $\mathrm{P}_{\mathrm{wmax}}=20 \mathrm{MPa} の$ 安定した潤 滑状態で得られた振動波形と比較して, $\mathrm{P}_{\mathrm{wmax}}=$ $23.2 \mathrm{MPa}$ 荷重条件では潤滑状態が苛酷になり $\theta_{\mathrm{c}}=+90^{\circ}$ 近傍の振動スパイクに顕著な増加が認 められる。 そして焼付きが発生する直前の $\mathrm{P}_{\mathrm{wmax}}=$ $24.2 \mathrm{MPa}$ の荷重条件では, 潤滑状態が極めて苛酷 になり $\theta_{\mathrm{c}}=+90^{\circ}$ 近傍の振動スパイクが大幅に増 大する特徵が認められる。そこで 3.1 節で適用した 異常振動の診断法と同様に, $\mathrm{P}_{\mathrm{wmax}}=20 \mathrm{MPa}$ の安定 した潤滑状態で得られた振動スパイクの絶対值 $V_{0}$

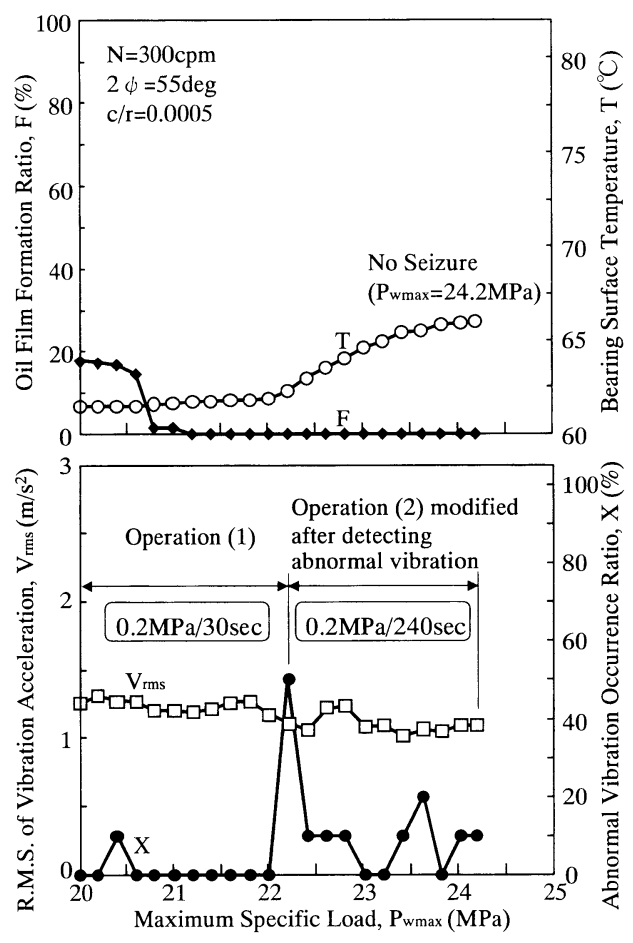

図16 Improved load carrying capacity by modified operation after detecting abnormal vibration
から，しきい值 $\mathrm{V}_{\mathrm{cr}}\left(=1.2 \mathrm{~V}_{\mathrm{o}}\right)$ を定めて 10 サイクル 中でしきい值を超えた異常振動発生率Xを計測す る方法で異常診断を実施した。

図15は $\mathrm{P}_{\text {wmax }}$ 值を $20 \mathrm{MPa}$ から段階的に増大させて 焼付きが発生するまでの油膜形成率 $F$, 軸受表面温 度 $\mathrm{T}$, 振動加速度の実効值 $\mathrm{V}_{\mathrm{rms}}$, 並びに異常振動発 生率Xの変化を調べた結果である. 表面温度Tおよ び振動加速度 (実効值) $\mathrm{V}_{\mathrm{rms}}$ の值は $\mathrm{P}_{\mathrm{wmax}}=24.0 \mathrm{MPa}$ の荷重条件で急增し，その直後に焼付きが発生し た。一方, 油膜形成率の值は焼付き発生限界の軸 受面圧 $\left(\mathrm{P}_{\mathrm{wmax}}=24.2 \mathrm{MPa}\right)$ と比較してかなり低い荷 重条件で0\%まで低下している。従って表面温度， 振動加速度 (実効值), 並びに油膜形成率の変化に 基づいて焼付き発生の予知診断を実施することは 困難であることがわかる。これに対して異常振動 発生率Xが50\%を越え, 高い振幅の振動スパイク が頻繁に発生することを異常診断の基準に考える と, $\mathrm{P}_{\mathrm{wmax}}=23.2 \mathrm{MPa}$ の荷重条件で潤滑状態の異常 を検知でき, 焼付き発生防止のための診断法とし て有効であることがわかる。

\subsection{2 異常振動検知後に運転方式を変更し焼付} き発生を防止した例図16は異常振動発生率X が50\%を越え潤滑状態の異常を検知できた直後に， 運転方式を変更して潤滑状態の変化を調べた結果 である。異常振動の検知後は四 17 に示すように $\mathrm{P}_{\mathrm{wmax}}$ 值の増加率を $0.2 \mathrm{MPa} / 30$ 秒から $0.2 \mathrm{MPa} /$

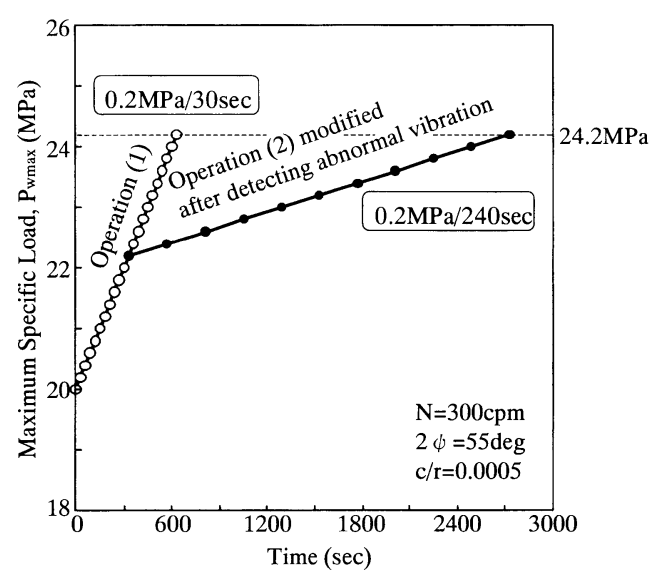

図17 Modified operation after detecting abnormal vibration 
240 秒に変更した. 図 16 から $\mathrm{P}_{\mathrm{wmax}}=22.2 \mathrm{MPa}$ の荷 重条件で異常振動発生率Xが50\%を越え潤滑状態 の異常を検知できたので，その直後に運転方式を 変更すると油膜破断部で油膜の修復が行える時間 が増大し，なじみが促進されたため異常振動発生 率が大幅に低下することがわかる。その結果, 運 転方式を変更しなかった場合の焼付き発生限界面 圧 $\left(\mathrm{P}_{\mathrm{wmax}}=24.2 \mathrm{MPa}\right)$ まで荷重を増大させても焼付 き発生には至らなかった。

以上の結果から, $\theta_{\mathrm{c}}=+90^{\circ}$ 近傍における振動 スパイクの増大とその発生頻度に着目した異常振 動発生率を用い異常診断を実施すると, 過酷な固 体接触が発生した初期段階で潤滑状態の異常を検 知でき，その直後に適正ななじみ運転を実施する ことにより潤滑状態が改善され焼付き発生を防止 できることがわかった。

今後は潤滑油温度の上昇, 回転速度の低下, 並 びに異物の混入などによる焼付き試験を実施し， 本研究で適用した異常診断法の有効性について検 討していく予定である.

\section{4. 結 論}

実際機関のクロスヘッド軸受と同様な変動荷重, 摇動滑りの条件で焼付き試験が実施できる軸受試 験機の振動状態をモニタリングし潤滑状態の異常 診断について検討した結果, 以下のことが明らか になった。

（1）クロスヘッド軸受の振動波形は1サイクルに 2 回すなわち摇動方向が反転するクランク角 度 $\theta_{\mathrm{c}}=-90^{\circ}$ および+ $90^{\circ}$ 近傍で振動スパ イクが発生する特徴がある。潤滑状態が苛 酷になると $\theta_{\mathrm{c}}=+90^{\circ}$ 近傍における振動ス パイクの増大が顕著になる.

（2）軸受表面温度, 振動加速度 (実効值), 並び に油膜形成率の変化に基づいて異常診断を 実施し焼付き発生を防止することは困難で ある。

(3) $\theta_{\mathrm{c}}=+90^{\circ}$ 近傍における振動スパイクの増 大とその発生頻度に着目した異常振動発生 率を用い異常診断を実施すると, 苛酷な固 体接触が発生した初期段階で閏滑状態の異 常を検知できる。
（4）異常振動の検知後に適正ななじみ運転を実 施すると潤滑状態が改善され，焼付き発生 の防止に有効である.

\section{謝 辞}

終わりに本研究の一部は, 平成 14 年度・造船学 術推進機構からの補助金により実施したものであ る。また試験の実施に際し, 大同メタル工業 (株) 第2カンパニー, MAN B\&W Diesel A/S, Research \& Development, 並びに新日本石油 (株) 潤滑油研 究所の関係各位から御協力をいただいた。ここに 深く謝意を表します。

\section{参考文献}

1）和栗雄太郎 - 小山田哲也 - 山本鷹司 - 堂園陽一, 日本 機械学会論文集, 27 巻178号 (1961-6), pp.910～918.

2) 和栗雄太郎 - 浜武俊朗 - 副島光洋, 日本舶用機関学会 誌, 22 巻3号 (1987-3), pp.207 218.

3) 和栗雄太郎 - 浜武俊朗 - 副島光洋 - 大坪勝, 日本舶用 機関学会誌, 26 卷 4 号 (1991-4), pp.158 166.

4) 和栗雄太郎 - 北原辰巳 - 浜武俊朗 - 副島光洋 - 平田昭 彦, 日本機械学会論文集 C 編, 63 卷 612 号（1997-8）, pp. $2832 \sim 2838$.

5) 北原辰巳 - 和栗雄太郎 - 浜武俊朗 - 藤崎宏太郎, 日本 機械学会論文集C 編, 65巻636号（1999-8），pp.3401～ 3407.

6) 日本トライボロジー学会編, トライボロジーハンドブ ック (2001-3), pp. 801 ～811.

7) Sasaki, S., Proc. of the 6th International Symposium on Marine Engineering, ISME Tokyo 2000, (2000-10), pp. $959 \sim 964$.

8) 木村隆一 - 寺嶋航 - 中井昇 - 山田哲男 - 武田象, 日本 舶用機関学会誌, 33巻10号 (1998-10), pp.738〜745.

9) 冨田展久 ・大久保稔, 日本マリンエンジニアリング学 会誌, 38 巻 3 号 $(2003-3), p p .107 \sim 112$.

10) 北原辰巳 - 大坪勝 - 藤崎宏太郎 - 岡戸篤 - 山田素平, 日本機械学会論文集 C編, 68巻665号（2002-1）, pp.255 $\sim 262$.

11）和栗雄太郎 - 朝鍋定生 - 高野一也, 潤滑, 10 巻 2 号 (1965-2), pp.109 116.

12) 北原辰巳 - 藤崎宏太郎 - 岡戸篤, 日本機械学会論文集 C編, 69巻681号（2003-5), pp.1404 1409. 